\title{
A Note on Terms
}

Three problems of terminology in this study involved institutions, groups, and geography. The Board of Proprietors of the Eastern Division of New Jersey was a major party to the land disputes, and largely for reasons of style I have referred to that organization as the "Board" and the "East Jersey Proprietors." I have in spots discussed the Western Society of Proprietors, referring to that institution as the "Western Society" or the "Western Proprietors." Some among those claiming lands via a proprietary title did not sit on either proprietary board, and I have referred to them (and to all those claiming lands under title from either the Board or the Western Society) as "proprietors," the "proprietary interests," and the "proprietary party," again largely for reasons of style. I have also used the terms "gentry," "great gentry," and "patricians" to describe the elite of the colony, of which the proprietors were a part. Again, this was done largely for reasons of style.

Those claiming land via nonproprietary title came from many ethnic groups, towns, and villages. The origins of their claims were diverse, and their involvement in the conflicts waxed and waned. The need to balance the specific with the general has led me to deploy a variety of terms to describe them. I have referred to them at various times as "the disaffected," "rioters," "land claimers," "clubmen," "yeomen freeholders," "plebeians," and "the coalition"; by their geographic origins ("Newarker," "Peapackers" ); and by the origins of their title ("squatter," "ElizabethTown claimers," "Indian Claimer").

Finally, a problem of geography and politics made labeling the areas in dispute somewhat problematic. In the 1670s, New Jersey was divided into the discrete colonies of East and West Jersey, with a line of division running from the Atlantic coast in the southeast to the hills of the northwest. The eastern 
portion was dominated by New Englanders and Dutch while the western portion was primarily settled by Quakers. The royalization of the colonies' government in $\mathrm{I}^{\mathrm{O}} \mathrm{O}-2$ led to the political reunion of the two sections, but each retained its own capital and its own proprietors (the aforementioned Eastern Board and Western Society). Overwhelmingly, eighteenth-century resistance to the land claims of the proprietary interests was centered in East Jersey, but the people from the West Jersey towns of Maidenhead, Hopewell, and the Great Tract, all in Hunterdon County, joined in direct actions against the proprietary interests. These towns, like the East Jersey communities to which they were culturally akin, were in what we today would call northern New Jersey. I have used that term occasionally when I felt it was appropriate to generalize, as well as the more specific East and West Jersey. 